PIOTR DZIKOWSKI

\title{
Business cycle and innovation activity in medium-high and high technology industry in Poland
}

Piotr Dzikowski, Ph.D. University of Zielona Góra, Faculty of Economics and Management

\section{Introduction}

In recent years, the global economy was in a period of economic slowdown. Today, there is a process of slow recovery from the crisis, as evidenced by various macroeconomic indicators. The current phase of the business cycle is an important determinant of decisions in the field of promoting or limiting innovation activity in manufacturing companies, both worldwide and in Poland. According to the economic literature different phases of business cycle affect the dynamics of innovation activity, but this influence depends on whether innovation activity is driven by demand or supply. Supply-side approach is accented by J. Schumpeter, who introduced the concept of "creative destruction" assuming that the downturn is an opportunity to innovate (Pomykalski 2001, p.16). This concept empirically documented Gerhard Mensch, who has shown that new technologies are often implemented during the recession as a consequence of identifying opportunities to survive in the shrinking market. He is also the author of the hypothesis of "technology push" (Mensch 1979, p.14). A different 
approach assumes that innovation is generated due to the demand mechanism (Schmookler, 2009, p.313). The relationship between fluctuations in demand and technology development has been identified (Kleinknecht, Verspagen, 1990, pp. 387-394). Furthermore, the positive relationship between the level of economic activity and innovative activity was noticed. (Geroski, Walters 1995, pp. 916-928). Hence, there was a need to take into account the two models in one concept, which also takes into account the flow of knowledge between business and academia and government centers.

In the end the innovation was defined as the outcome of the knowledge absorption process with various sources, whereas the flow of knowledge is a result of mutual interactions between the enterprises and other market participants (Rogut 2007, p. 7). It's a multifaceted process that occurs continuously, but its intensity depends on many factors including the economic condition. In the period of recovery and growth in market demand innovation activity increases (Clark, Freeman, Soete 1981, pp. 308-322). An important role is played by an intensity of both R\&D and knowledge transfer between companies belonging to different industries. All these elements demonstrate the complex nature of the innovation process (Świtalski 2005, p. 66). The latest research concerning the relationship between business cycle and the innovation activity of the Polish Industry System show that in the prosperity phase the implementation of the innovation activity is significantly higher. However, during recession and stagnation, it is a less common phenomenon, but it is not completely abandoned. Hence, the economic situation is an important decision-making factor, which affects the innovation activity (Świadek 2014, p.1).

In this context, it may be interesting to understand what impact each phase of business cycle has on innovation activity in the group of enterprises with the same level of technology. The aim of the study is to find and compare statistically significant trends and the impact of business cycle phases on innovation activity in medium-high and high technology enterprises in Poland. It is assumed that each phase of the business cycle affects each kind of innovation activity in the same way (by facilitating it or reducing it). In contrast, the intensity of this influence varies and depends on the propensity to undertake innovation activity. The least likely innovation activities (having the lowest absolute probabilities) are the most vulnerable. The results of the study are part of the results obtained from the analysis conducted on determinants of innovation of industrial enterprises in every region in Poland. After gathering data from all Polish regions a unique subset of data set representing both MHT and HT industries is selected. 


\section{Medium-high and high technology industries structure and introduction to innovation}

Manufacturing industries can be grouped into four categories according to their research and development (R\&D) intensity: high, medium-high, mediumlow and low technology. They are classified using the ISIC ${ }^{1}$. The classification is based on a ranking which uses data on R\&D expenditure divided by value added, and R\&D expenditure divided by production for 12 OECD countries during the period 1991-992. The high-technology group includes: pharmaceuticals, office, accounting and computing machinery, radio, television and communication equipment, medical, precision and optical instruments, aircraft and spacecraft whereas the medium-high-technology group is composed of: chemicals excluding pharmaceutical, machinery and equipment not elsewhere classified, electrical machinery and apparatus not elsewhere classified, motor vehicles, trailers and semi-trailers, railroad equipment and transport equipment not elsewhere classified (Hatzichronoglou 1997).

Innovation is a complex and multifaceted phenomenon. It can be defined as a process or a result of a series of actions (Dolińska 2010, p.13). The typical innovation process includes several stages such as creation of the idea, research and development, design, production and dissemination (Stawasz 1999, pp.2425). The result refers to any good, service or idea that is perceived by the customer as new (Pomykalski 2001, p.17). According to the definition introduced by OECD „An innovation is the implementation of a new or significantly improved product (good or service), or process, a new marketing method, or a new organizational method in business practices, workplace organization or external relations" (Oslo Manual 2005, p.46). Innovation is the result of various scientific, technical, organizational, financial and commercial activities that lead or are intended to lead to their implementation. It is assumed that there are three kinds of innovation activity: (1) research and development (R\&D), (2) acquisition of knowledge in the form of patents, licenses, technical services, (3) the purchase of innovative machinery and equipment necessary to produce new processes and production of new products (Janasz, Kozioł-Nadolna 2011, pp.18-19). Firms can support a rich set of specific innovation activities to develop or acquire

1 ISIC is the United Nations International Standard industrial Classification of all economic activities.

2 USA, Canada, Japan, Denmark, Finland, France, Germany, Ireland, Italy, Spain, Sweden and Great Britain. 
innovations. It may include: (a) R\&D to develop new product or process concepts and occasionally marketing or organizational innovations, (b) buying technical information (paying fees or royalties for patented inventions, purchasing trademarks or buying know-how), (c) investing in equipment, machines and software or in land or buildings (including enhancements, modifications and repairs) required to implement product and process innovations, (d) developing human skills and new methods of marketing new or enhanced goods, (e) other activities such as designing, planning and testing new products and services, process implementations or production methods (Dwojacki, Hlousek 2008, p.48).

\section{Methodology}

The methodological part of this analysis is based on probity modeling. This instrument allows the researcher to determine the probability of innovative behaviors in relation to a firm size and its ownership (Liao, 1994, s.10). All models meet the following assumptions: (1) the data came from a random sample, (2) Y can take only two values: 0 or 1, (3) subsequent $Y$ values are statistically independent, (4) the probability that $Y=1$ is defined by normal distribution for the probity or logistic distribution for logit model. There is no perfect linear relationship between the variables in the logit model Xi (Lipiec-Zajchowska 2003, pp.12930). Parameter estimation is performed using the maximum likelihood method (MLE). It allows us to find a vector of parameters that guarantees the highest probability of obtaining the observed value of the sample (Welfe 1998, pp. 736). MLE requires the definition of likelihood function and finding its extreme. The nonlinear estimation procedure uses a quasi-Newton algorithm to find the minimum of the loss function. In this way, a collection of the best estimators for the loss function is calculated (Stanisz 2007, pp.190-191). Maximizing the likelihood function for the probity model is made using the techniques used in the nonlinear estimation (Maddala 2006, p. 373).

It is assmued that all relations are linear equations, because both innovation activities (the dependent variables) and business cycle phases (independent variables) are binary. Every model is described by two probabilities. P1 determines the probability of innovation activity under the influence of a given phase and P2 determines the probability of innovation activity in all other phases together. If the function parameter is positive $(a>0)$, then P1 takes higher value in a given group. All statistically significant models include standard error (Std), t-Student statistic, the probability of non-significant parameter $(\mathrm{P}>|\mathrm{z}|)$ and the probability of non-significant model $(\mathrm{P})$. 


\section{Research sample}

The scope of this study concerns innovation activity in medium-high and high technology industry at the level of firm and new to the firm. The survey is based on a questionnaire sent by email or conducted during a telephone interview with a manager or company founder. All data was gathered between 20082013 in Poland. Information was collected from every Polish region and stored in a database based on commercial and non-commercial sources of information such as Teleadreson, PKT and others. The success rate is about $15 \%$. Due to the size of the research task data collection was carried out by regions. The structure of the data in each region corresponded to a regional structure of industrial companies described by the Central Statistical Office (GUS). The data collected from all regions was stored in one database. By selecing MHT and HT enterprises the unique subset was built. It included data representing both MHT and HT industries from all Polish regions. The share of MHT\&HT industries in Polish economy in 2013 was 14,3\% (GUS, s.44). Hence, 1355 enterprises represent 5,15\% of the total both MHT \& HT companies in Poland, including $981(72,4 \%)$ from medium-high technology industry and 374 (27,6\%) from high technology one. Table 2 shows the structure of research data by technology and firm size.

Table 1. Enterprises by technology and firm size

\begin{tabular}{l|c|c|c|c|c|c|c|c|c|c}
\hline Technology & \multicolumn{2}{|c|}{ Micro } & \multicolumn{2}{c|}{ Small } & \multicolumn{2}{c|}{ Medium } & \multicolumn{2}{c|}{ Large } & \multicolumn{2}{c}{ Total } \\
\hline Medium-high & 252 & $25,69 \%$ & 350 & $35,68 \%$ & 275 & $28,03 \%$ & 104 & $10,60 \%$ & 981 & $72,4 \%$ \\
\hline High & 172 & $45,99 \%$ & 103 & $27,54 \%$ & 66 & $17,65 \%$ & 33 & $8,82 \%$ & 374 & $27,6 \%$ \\
\hline Total & 424 & $31,29 \%$ & 453 & $33,43 \%$ & 341 & $25,17 \%$ & 137 & $10,11 \%$ & 1355 & $100 \%$ \\
\hline
\end{tabular}

Source: own study

Table 2. Companies by industry groups (PKD symbol)

\begin{tabular}{l|c|c|c}
\hline PKD Symbol & $\begin{array}{c}\text { Number of } \\
\text { firms }\end{array}$ & $\begin{array}{c}\text { Industry share in a } \\
\text { given group(\%) }\end{array}$ & $\begin{array}{c}\text { Industry share in } \\
\text { both groups (\%) }\end{array}$ \\
\hline $\begin{array}{l}\text { 33 Manufacture of instruments and } \\
\text { appliances for measuring, testing and } \\
\text { navigation; watches and clocks }\end{array}$ & 187 & 50,00 & 13,80 \\
\hline
\end{tabular}

97

PIOTR DZIKOWSKI 


\begin{tabular}{|c|c|c|c|}
\hline $\begin{array}{l}24.4 \text { Manufacture of basic pharmaceuti- } \\
\text { cal products and pharmaceutical prepa- } \\
\text { rations }\end{array}$ & 60 & 18,72 & 5,17 \\
\hline $\begin{array}{l}32 \text { Manufacture of communication } \\
\text { equipment }\end{array}$ & 70 & 16,04 & 4,43 \\
\hline $\begin{array}{l}30 \text { Manufacture of computers and pe- } \\
\text { ripheral equipment }\end{array}$ & 52 & 13,90 & 3,84 \\
\hline $\begin{array}{l}35.3 \text { Manufacture of air and spacecraft } \\
\text { and related machinery }\end{array}$ & 5 & 1,34 & 0,37 \\
\hline Total high technology & 374 & 100 & 27,60 \\
\hline $\begin{array}{l}29 \text { Manufacture of machinery and equip- } \\
\text { ment }\end{array}$ & 480 & 48,93 & 35,42 \\
\hline 31 Manufacture of electrical equipment & 227 & 23,14 & 16,75 \\
\hline $\begin{array}{l}24 \text { without } 24.4 \text { Manufacture of chemi- } \\
\text { cals and chemical products }\end{array}$ & 156 & 15,90 & 11,51 \\
\hline $\begin{array}{l}34 \text { Manufacture of motor vehicles, trail- } \\
\text { ers and semi-trailers }\end{array}$ & 82 & 8,36 & 6,05 \\
\hline $\begin{array}{l}35.5 \text { Manufacture of other transport } \\
\text { equipment }\end{array}$ & 21 & 2,14 & 1,55 \\
\hline $\begin{array}{l}35.2 \text { Manufacture of railway locomotives } \\
\text { and rolling stock }\end{array}$ & 15 & 1,53 & 1,11 \\
\hline Total medium-high technology & 981 & 100 & 72,40 \\
\hline
\end{tabular}

Source: own study

National capital represents 1105 enterprises (81,55\%) whereas foreign capital firms include 142 companies (10,48\%) and 108 (7,97\%) units have mix capital. Table 3 shows the data set by industry (PKD symbol).

\section{The impact of business cycle phases on innovation activities}

54 models were found, but $36(66,67 \%)$ are statistically significant that is their confidence interval is lower than $\mathrm{p} \leq 0.05(5 \%))$. When dividing the probability $\mathrm{P} 1$ by the probability $\mathrm{P} 2$, it is possible to calculate the intensity of influence for a given business cycle phase. 
Fourteen out of eighteen models were statistically significant for the economic prosperity phase. Thus, this phase has a significant impact on innovative activity. All models have a positive coefficient, which proves that it is a positive influence. The economic prosperity has the greatest influence on those innovation activities which are taken few (having the lowest absolute probability values) i.e. cooperation with the science institutions. The increase concerns such areas as: cooperation with foreign R\&D units (+300\%), cooperation with universities $(+120 \%)$ and cooperation with domestic R\&D units $(+70 \%)$.

On the other hand the influence is the lowest for those innovation activities which are taken most frequently (having the highest absolute probability values). It concerns: implementation of new technology processes $(+17 \%)$, investment in new fixed assets (18\%) and lauching new products (19\%). All probit models for the economic prosperity sorted by intensity of influence are introduced in table 3 .

Table 3. Probit models for the economic prosperity sorted by intensity of influence

\begin{tabular}{|c|c|c|c|c|c|c|c|c|}
\hline Innovation feature & Coef & $\begin{array}{l}\text { Std. } \\
\text { error }\end{array}$ & t-test & $P>|z|$ & P1 & P2 & $\mathbf{P}$ & $\begin{array}{c}\mathrm{P} 1 / \mathrm{P} 2 \\
(\%)\end{array}$ \\
\hline Cooperation with foreign $R \& D$ units & $+0,50$ & 0,17 & 2,87 & 0,00 & 0,04 & 0,01 & 0,00 & 300,00 \\
\hline Cooperation with universities & $+0,37$ & 0,11 & 3,44 & 0,00 & 0,11 & 0,05 & 0,00 & 120,00 \\
\hline $\begin{array}{l}\text { Cooperation with domestic } R \& D \\
\text { units }\end{array}$ & $+0,34$ & 0,09 & 3,75 & 0,00 & 0,17 & 0,10 & 0,00 & 70,00 \\
\hline $\begin{array}{l}\text { Investment in new fixed assets } \\
\text { (including): buildings and grounds } \\
\text { required to implement new prod- } \\
\text { ucts and processes }\end{array}$ & $+0,38$ & 0,08 & 4,97 & 0,00 & 0,33 & 0,21 & 0,00 & 57,14 \\
\hline$R \& D$ expenditure & $+0,50$ & 0,07 & 7,05 & 0,00 & 0,59 & 0,39 & 0,00 & 51,28 \\
\hline $\begin{array}{l}\text { Implementation of new technology } \\
\text { processes (including): new produc- } \\
\text { tion methods }\end{array}$ & $+0,41$ & 0,07 & 5,78 & 0,00 & 0,55 & 0,39 & 0,00 & 41,03 \\
\hline Cooperation with suppliers & $+0,25$ & 0,08 & 3,30 & 0,00 & 0,31 & 0,22 & 0,00 & 40,91 \\
\hline Overall innovation cooperation & $+0,34$ & 0,07 & 4,87 & 0,00 & 0,57 & 0,43 & 0,00 & 32,56 \\
\hline Investment in computer software & $+0,38$ & 0,07 & 5,28 & 0,00 & 0,75 & 0,61 & 0,00 & 22,95 \\
\hline
\end{tabular}




\begin{tabular}{l|c|c|c|c|c|c|c|c}
$\begin{array}{l}\text { Implementation of new technology } \\
\text { processes (including): non produc- } \\
\text { tion systems }\end{array}$ & $+\mathbf{0 , 1 8}$ & $\mathbf{0 , 0 7}$ & $\mathbf{2 , 5 8}$ & $\mathbf{0 , 0 1}$ & $\mathbf{0 , 3 9}$ & $\mathbf{0 , 3 2}$ & $\mathbf{0 , 0 1}$ & $\mathbf{2 1 , 8 8}$ \\
\hline $\begin{array}{l}\text { Investment in new fixed assets } \\
\text { (including): technical equipment } \\
\text { and machin ery }\end{array}$ & $+0,37$ & $\mathbf{0 , 0 7}$ & $\mathbf{5 , 0 2}$ & $\mathbf{0 , 0 0}$ & $\mathbf{0 , 7 5}$ & $\mathbf{0 , 6 2}$ & $\mathbf{0 , 0 0}$ & $\mathbf{2 0 , 9 7}$ \\
\hline Lauching new products & $+\mathbf{0 , 2 7}$ & $\mathbf{0 , 0 7}$ & $\mathbf{3 , 8 6}$ & $\mathbf{0 , 0 0}$ & $\mathbf{0 , 6 8}$ & $\mathbf{0 , 5 7}$ & $\mathbf{0 , 0 0}$ & $\mathbf{1 9 , 3 0}$ \\
\hline Investment in new fixed assets & $+\mathbf{0 , 4 2}$ & $\mathbf{0 , 0 8}$ & $\mathbf{5 , 4 9}$ & $\mathbf{0 , 0 0}$ & $\mathbf{0 , 8 3}$ & $\mathbf{0 , 7 0}$ & $\mathbf{0 , 0 0}$ & $\mathbf{1 8 , 5 7}$ \\
\hline $\begin{array}{l}\text { Implementation of new technology } \\
\text { processes }\end{array}$ & $+0,38$ & 0,08 & 5,07 & 0,00 & 0,81 & 0,69 & 0,00 & $\mathbf{1 7 , 3 9}$ \\
\hline
\end{tabular}

Source: own study

Eight out of eighteen models were statistically significant for the recession. All models have a negative coefficient, which suggests that it is a negative influence. The recession has the greatest influence on those innovation activities which are taken few. The decrease concerns such areas as: cooperation with domestic R\&D units (-46\%), investment in new fixed assets (including): buildings and grounds required to implement new products and processes $(-27 \%)$ and implementation of new technology processes (including): non production systems (-26\%).

On the other hand the influence is the lowest for the most frequently undertaken activities: lauching new products (-12\%), investment in new fixed assets (-13\%) including technical equipment and machinery $(-15 \%)$. All probit models for the recession sorted by intensity of influence are showed in table 4 .

Table 4. Probit models for the recession sorted by intensity of influence

\begin{tabular}{l|c|c|c|c|c|c|c|c}
\hline Innovation feature & Coef & $\begin{array}{c}\text { Std. } \\
\text { error }\end{array}$ & t-test & $\mathbf{P}>|\mathrm{z}|$ & $\mathbf{P 1}$ & $\mathbf{P 2}$ & $\mathbf{P}$ & $\begin{array}{c}\mathbf{P 1 / P 2} \\
\mathbf{( \% )}\end{array}$ \\
\hline $\begin{array}{l}\text { Cooperation with domestic R\&D } \\
\text { units }\end{array}$ & $-\mathbf{0 , 3 4}$ & $\mathbf{0 , 1 4}$ & $-\mathbf{2 , 5 0}$ & $\mathbf{0 , 0 1}$ & $\mathbf{0 , 0 8}$ & $\mathbf{0 , 1 5}$ & $\mathbf{0 , 0 0}$ & $-\mathbf{4 6 , 6 7}$ \\
\hline $\begin{array}{l}\text { Investment in new fixed assets } \\
\text { (including): buildings and grounds } \\
\text { required to implement new prod- } \\
\text { ucts and processes }\end{array}$ & $-\mathbf{0 , 2 8}$ & $\mathbf{0 , 1 1}$ & $-\mathbf{2 , 5 2}$ & $\mathbf{0 , 0 1}$ & $\mathbf{0 , 2 1}$ & $\mathbf{0 , 2 9}$ & $\mathbf{0 , 0 1}$ & $\mathbf{- 2 7 , 5 9}$ \\
\hline
\end{tabular}




\begin{tabular}{l|c|c|c|c|c|c|c|c}
\hline $\begin{array}{l}\text { Implementation of new technology } \\
\text { processes (including): non produc- } \\
\text { tion systems }\end{array}$ & $-\mathbf{0 , 2 5}$ & $\mathbf{0 , 1 0}$ & $-\mathbf{2 , 4 1}$ & $\mathbf{0 , 0 2}$ & $\mathbf{0 , 2 8}$ & $\mathbf{0 , 3 8}$ & $\mathbf{0 , 0 2}$ & $\mathbf{- 2 6 , 3 2}$ \\
\hline R\&D expenditure & $-\mathbf{0 , 3 2}$ & $\mathbf{0 , 1 0}$ & $-\mathbf{3 , 2 4}$ & $\mathbf{0 , 0 0}$ & $\mathbf{0 , 4 0}$ & $\mathbf{0 , 5 3}$ & $\mathbf{0 , 0 0}$ & $\mathbf{- 2 4 , 5 3}$ \\
\hline Overall innovation cooperation & $-\mathbf{0 , 2 4}$ & $\mathbf{0 , 1 0}$ & $-\mathbf{2 , 4 8}$ & $\mathbf{0 , 0 1}$ & $\mathbf{0 , 4 3}$ & $\mathbf{0 , 5 3}$ & $\mathbf{0 , 0 1}$ & $\mathbf{- 1 8 , 8 7}$ \\
\hline $\begin{array}{l}\text { Investment in new fixed assets (in- } \\
\text { cluding): technical equipment and } \\
\text { machinery }\end{array}$ & $-\mathbf{0 , 2 9}$ & $\mathbf{0 , 1 0}$ & $-\mathbf{2 , 8 7}$ & $\mathbf{0 , 0 0}$ & $\mathbf{0 , 6 1}$ & $\mathbf{0 , 7 2}$ & $\mathbf{0 , 0 0}$ & $\mathbf{- 1 5 , 2 8}$ \\
\hline Investment in new fixed assets & $-\mathbf{0 , 3 4}$ & $\mathbf{0 , 1 0}$ & $-\mathbf{3 , 3 0}$ & $\mathbf{0 , 0 0}$ & $\mathbf{0 , 6 9}$ & $\mathbf{0 , 8 0}$ & $\mathbf{0 , 0 0}$ & $\mathbf{- 1 3 , 7 5}$ \\
\hline Launching new products & $-\mathbf{0 , 2 1}$ & $\mathbf{0 , 1 0}$ & $-\mathbf{2 , 1 5}$ & $\mathbf{0 , 0 3}$ & $\mathbf{0 , 5 7}$ & $\mathbf{0 , 6 5}$ & $\mathbf{0 , 0 3}$ & $\mathbf{- 1 2 , 3 1}$ \\
\hline
\end{tabular}

Source: own study

Fourteen out of eighteen models were statistically significant for the economic stagnation which proves that this phase has very high influence. All models have a negative coefficient, which suggests that it is a negative influence. The economic stagnation has the greatest influence on those innovation activities which are taken few. The decrease concerns cooperation with foreign R\&D units $(-66 \%)$, cooperation with universities $(-60 \%)$ and implementation of new technology processes (including): new production methods (-35\%). The influence is the lowest for the most frequently undertaken activities such as: investment in new fixed assets (-11\%), launching new products $(-12 \%)$ and investment in new fixed assets (including): technical equipment and machinery (-12\%). All probit models for the economic stagnation sorted by intensity of influence are showed in table 5.

Table 5. Probit models for the economic stagnation sorted by intensity of influence

\begin{tabular}{l|c|c|c|c|c|c|c|c}
\hline Innovation feature & Coef & $\begin{array}{c}\text { Std. } \\
\text { error }\end{array}$ & t-test & $\mathbf{P}>|\mathbf{z}|$ & $\mathbf{P 1}$ & $\mathbf{P 2}$ & $\mathbf{P}$ & $\begin{array}{c}\mathbf{P 1 / P 2} \\
\mathbf{( \% )}\end{array}$ \\
\hline Cooperation with foreign R\&D units & $-\mathbf{0 , 5 3}$ & $\mathbf{0 , 2 2}$ & $-\mathbf{2 , 3 2}$ & $\mathbf{0 , 0 2}$ & $\mathbf{0 , 0 1}$ & $\mathbf{0 , 0 3}$ & $\mathbf{0 , 0 0}$ & $-66,67$ \\
\hline Cooperation with universities & $-\mathbf{0 , 4 3}$ & $\mathbf{0 , 1 3}$ & $-3,23$ & $\mathbf{0 , 0 0}$ & $\mathbf{0 , 0 4}$ & $\mathbf{0 , 1 0}$ & $\mathbf{0 , 0 0}$ & $-60,00$ \\
\hline $\begin{array}{l}\text { Implementation of new technology } \\
\text { processes (including): new produc- } \\
\text { tion methods }\end{array}$ & $-\mathbf{0 , 4 9}$ & $\mathbf{0 , 0 8}$ & $-6,07$ & $\mathbf{0 , 0 0}$ & $\mathbf{0 , 3 4}$ & $\mathbf{0 , 5 3}$ & $\mathbf{0 , 0 0}$ & $-35,85$ \\
\hline
\end{tabular}




\begin{tabular}{|c|c|c|c|c|c|c|c|c|}
\hline Cooperation with suppliers & $-0,30$ & 0,09 & $-3,41$ & 0,00 & 0,20 & 0,30 & 0,00 & $-33,33$ \\
\hline $\begin{array}{l}\text { Investment in new fixed assets } \\
\text { (including): buildings and grounds } \\
\text { required to implement new prod- } \\
\text { ucts and processes }\end{array}$ & $-0,31$ & 0,09 & $-3,55$ & 0,00 & 0,21 & 0,31 & 0,00 & $-32,26$ \\
\hline$R \& D$ expenditure & $-0,45$ & 0,08 & $-5,56$ & 0,00 & 0,38 & 0,56 & 0,00 & $-32,14$ \\
\hline $\begin{array}{l}\text { Cooperation with domestic } R \& D \\
\text { units }\end{array}$ & $-0,21$ & 0,10 & $-2,04$ & 0,04 & 0,11 & 0,15 & 0,04 & $-26,67$ \\
\hline $\begin{array}{l}\text { Implementation of new technology } \\
\text { processes (including): non produc- } \\
\text { tion systems }\end{array}$ & $-0,24$ & 0,09 & $-2,83$ & 0,00 & 0,24 & 0,32 & 0,00 & $-25,00$ \\
\hline Overall innovation cooperation & $-0,30$ & 0,08 & $-3,83$ & 0,00 & 0,42 & 0,54 & 0,00 & $-22,22$ \\
\hline Investment in computer software & $-0,39$ & 0,08 & $-4,86$ & 0,00 & 0,58 & 0,73 & 0,00 & $-20,55$ \\
\hline $\begin{array}{l}\text { Implementation of new technology } \\
\text { processes }\end{array}$ & $-0,41$ & 0,08 & $-4,85$ & 0,00 & 0,66 & 0,79 & 0,00 & $-16,46$ \\
\hline $\begin{array}{l}\text { Investment in new fixed assets } \\
\text { (including): technical equipment } \\
\text { and machinery }\end{array}$ & $-0,27$ & 0,08 & $-3,30$ & 0,00 & 0,63 & 0,72 & 0,00 & $-12,50$ \\
\hline Lauching new products & $-0,21$ & 0,08 & $-2,66$ & 0,00 & 0,58 & 0,66 & 0,00 & $-12,12$ \\
\hline Investment in new fixed assets & $-0,30$ & 0,09 & $-3,49$ & 0,00 & 0,71 & 0,80 & 0,00 & $-11,25$ \\
\hline
\end{tabular}

\section{Conclusions}

Innovation activity is heavily dependent on the business cycle phases in the medium-high or high-tech industry in Poland. Furthermore, this dependency is cyclical. During the economic prosperity enterprises take innovation activity more often whereas the recession and economic stagnation decreases it, but they do not stop it. The intensity of this influence depends on firm's innovation activity. The higher innovation activity the less impact of business cycle. All business cycle phases have the greatest influence on those innovation activities which are taken few. Most of them concern the cooperation with science institutions such as both domestic and national R\&D units and universities. The influence is the lowest for the most frequently undertaken activities such as investment in new 
fixed assets, implementation of new technology processes and launching new products. If we compare the influence of recession and economic stagnation, we see that higher values of $\mathrm{P} 1 / \mathrm{P} 2$ indicator are obtained in the case of the economic stagnation where the number of statistically significant models is almost twice. Business cycle affects innovation activity in medium-high and high technology industry very much, thus the innovation policy for this kind of industry should involve its vulnerability to business cycle. Medium-high and high technology industry has its own distinguishing characteristic, but it is subject to natural market laws. The analysis confirms that business cycle phases can accelerate or reduce innovation activity so considering them in designing both regional and national innovation policies can increase competitiveness.

\section{Abstract}

\section{Business cycle and innovation activity in medium-high and high technology industry in Poland}

This article examines differences in an impact of business cycle phases on innovation activity in medium-high and high technology industry in Poland. It is assumed that each business cycle phase influences innovation activity in the same fashion, but its impact varies and it depends on the firm's innovation activity. The higher innovation activity the less impact of business cycle. The scope of the survey relates to innovation in MHT and HT industry in Poland. The data concerns the innovation at the firm level and the diffusion "new for the company". Innovation activity is defined by the following activities: (1) expenditure on research and development and investments in fixed assets not used so far such as: a)buildings, premises and land; b) machinery and equipment, c) computer software; (2) implementation of new products and technological processes and (3) innovation cooperation. The methodological part of the analysis includes a logit modeling. The survey includes 1355 companies. Business cycle has a great influence on innovation activity in MTH and HT industry in Poland. The influence of recovery phase is positive whereas both stagnation and recession phases decrease the probability of innovation activity. The character of influence depends on the propensity to take innovation activity. The higher level of innovation activity the enterprises present the less influence of business cycle they get. 
Keywords: $\quad$ innovation, business cycle, industry, MHT, HT

\section{Streszczenie}

Koniunktura gospodarcza a aktywność innowacyjna systemów przemysłowych średnio-wysokiej i wysokiej techniki w Polsce Celem pracy jest znalezienie zależności zachodzących pomiędzy fazami cyklu koniunkturalnego a aktywnością innowacyjną przemysłu średnio-wysokiej i wysokiej techniki. Hipotezą badawczą jest założenie, że kierunek oddziaływania poszczególnych faz cyklu koniunkturalnego jest identyczny, natomiast ich siła oddziaływania zależy od skłonności przedsiębiorstw do podejmowania danego rodzaju działania innowacyjnego. Im większy jest poziom aktywności innowacyjnej przedsiębiorstwa tym mniejszym zmianom ona podlega. Prezentowany zakres badania dotyczy innowacji wśród przedsiębiorstw średnio-wysokiej i wysokiej techniki, charakteryzuje innowacje na poziomie firmy i uwzględnia dyfuzję do poziomu „nowość dla firmy”. Działania innowacyjne podzielono na trzy grupy obejmujące: (1) nakłady na badania i rozwój oraz inwestycje w dotychczas niestosowane środki trwałe w tym: a) budynki, lokale i grunty; b) maszyny i urządzenia techniczne, c) oprogramowanie komputerowe (2) implementacje nowych wyrobów i procesów technologicznych oraz (3) współpracę innowacyjną. Analizy wykonano na bazie 1355 przedsiębiorstw, a metodyka badawcza została oparta na modelowaniu probitowym. W badanej grupie przedsiębiorstw czynnik koniunkturalny silnie oddziałuje na ich zachowania innowacyjne. W fazie ożywienia przedsiębiorstwa częściej podejmują działania innowacyjne. Natomiast $\mathrm{w}$ czasie dekoniunktury i stagnacji aktywność innowacyjna przedsiębiorstw maleje. Siła oddziaływania poszczególnych faz zależy od skłonności przedsiębiorstw do podejmowania danego rodzaju działania innowacyjnego. Im większy jest poziom aktywności innowacyjnej przedsiębiorstwa tym mniejszym zmianom ona podlega pod wpływem poszczególnych faz cyklu koniunkturalnego.

\section{Slowa \\ kluczowe: innowacja, cykl koniunkturalny, przemyst, MHT, HT}




\section{References}

1. Clark J., Freeman C., Soete L. (1981), Long waves, inventions, and innovations,. Futures nr 13 (4).

2. Dolińska M.(2010), Innowacje w gospodarce opartej na wiedzy, PWE, Warszawa.

3. Dwojacki P., Hlousek J. (2008), Zarządzanie innowacjami, Centrum Badawczo-Rozwojowe, Gdańsk.

4. Geroski P., Walters C.F. (1995), Innovative Activity Over the Business Cycle, Economic Journal, 431.

5. Hatzichronoglou, T. (1997), "Revision of the High-Technology Sector and Product Classification", OECD Science, Technology and Industry Working Papers, No. 1997/02. doi: 10.1787/134337307632.

6. Janasz W., Kozioł-Nadolna K. (2011), Innowacje w organizacji, PWE, Warszawa.

7. Kleinknecht A., Verspagen B. (1990), Demand and Innovation: Schmookler Re-examined, Research Policy, 19 (4).

8. Liao T.F. (1994), Interpreting probability models: Logit, probit, and other generalized linear models, Sage University Paper series on Quantitative Applications in the Social Sciences, series no. 07-101, DA: Sage, Thousand Oaks.

9. Lipiec-Zajchowska M. (red.) (2003), Wspomaganie procesów decyzyjnych. Ekonometria, Wyd. C.H. Beck, Warszawa.

10. Maddala G. S. (2006), Ekonometria, PWN, Warszawa.

11. Mensch G.O. (1979), Stalemate In Technology - Innovations Overcome the Depression, Ballinger, Cambridge MA.

12. Oslo Manual (2005), Guidelines for collecting and interpreting innovation data, Third edition, Paris, 2005.

13. Pomykalski A. (2001), Zarządzanie innowacjami, PWN, Warszawa-Łódź.

14. Rogut A. (2007), Modele sektorowego systemu innowacji. Raport ze studiów literaturowych, Społeczna Wyższa Szkoła Przedsiębiorczości i Zarządzania w Łodzi, Łódź.

15. Schmookler J.(2009), Invention and Economic Growth, Harvard University Press, Cambridge Mass za S. Kubielas, Innowacje i luka technologiczna $w$ gospodarce globalnej opartej na wiedzy, Uniwersytet Warszawski, Warszawa.

16. Stanisz A. (2007), Przystępny kurs statystki, tom 2, Statsoft, Kraków.

17. Stawasz E. (1999), Innowacje a mała firma, Wydawnictwo Uniwersytetu Łódzkiego, Łódź.

18. Swiadek A. (2014), The economic cycle and the innovation activity of the Polish Industry System, Institute of Economic Research Working Papers, No. 50/2014, Torun.

19. Świtalski W. (2005), Innowacje i konkurencyjność, WUW, Warszawa.

20. Welfe A. (1998), Ekonometria, PWE. Warszawa. 